\title{
Gottlob Frege
}

\section{O pojęciu i przedmiocie}

[192] W serii opublikowanych w tym kwartalniku ${ }^{1}$ artykułów dotyczących naoczności i jej psychicznego przetwarzania Benno Kerry wielokrotnie odnosił się do Podstaw arytmetyki $i^{2}$ i innych moich prac, czasami zgadzając się z moimi poglądami, a czasami je kwestionując. Nie pozostaje mi nic innego, jak tylko z tego powodu się cieszyć. Sądzę, że najlepszym sposobem na okazanie mojej wdzięczności będzie przeanalizowanie punktów, które zakwestionował Kerry. Wydaje mi się to konieczne, tym bardziej że jego sprzeciw przynajmniej po części - wynika z mogącego udzielać się również innym

* Jest to tłumaczenie artykułu Gottloba Fregego, „Über Begriff und Gegenstand”, Vierteljahrsschrift für wissenschaftliche Philosophie 16 (1892): 192-205. W kwadratowych nawiasach, np. w zapisie [192], podajemy paginację z tego artykułu. Fragmenty tekstu i przypisy w nawiasach kwadratowych pochodzą od tłumaczy. W zapisie np. [192] podana jest paginacja z artykułu Fregego.

1 [Frege ma tutaj na myśli serię ośmiu artykułów „,̈ber Anschauung und ihre psychische Verarbeitung", które były publikowane w czasopiśmie Vierteljahrsschrift für wissenschaftliche Philosophie w numerach: 9 (1885): 433-493; 10 (1886): 419-467; 11 (1887): 53-116, 249-307; 13 (1889): 71-124, 392-419; 14 (1890): 317-353; 15 (1891): 127-167].

2 [Przez Podstawy arytmetyki rozumiemy tutaj pracę Fregego Gottloba, Die Grundlagen der Arithmetik. Eine logisch mathematische Untersuchung über den Begriff der Zahl (Breslau: Wilhelm Koebner, 1884). Jeśli chodzi o polskie tłumaczenie tej pracy, zob. Gottlob Frege, „Podstawy arytmetyki. Logiczno-matematyczne badania nad pojęciem liczby”, w: Próby gramatyki filozoficznej. Antologia: Franz Brentano, Gottlob Frege, Christian Thiel, przeł. i oprac. Krzysztof Rotter (Wrocław: Wydawnictwo Uniwersytetu Wrocławskiego, 1997)]. 
niezrozumienia tego, co mówię o pojęciu, i tym bardziej że sprawa jest na tyle ważna i trudna, by poświęcić jej więcej uwagi, niż przypuszczałem, pisząc moje Podstawy.

Wyraz „pojęcie” używany jest na różne sposoby; jego sens jest czasami psychologiczny, czasami logiczny, a czasami psychologiczny i logiczny zarazem. Tę swobodę [terminologiczną] w naturalny sposób ogranicza jednak wymóg, aby trzymać się przyjętego już sposobu użycia wyrazu. Zdecydowałem się na ścisłe zastosowanie czysto logicznego sensu, pytanie zaś o to, które użycie jest bardziej odpowiednie, chciałbym odłożyć na bok jako mało ważną sprawę. Można z łatwością dojść do porozumienia w kwestii sposobu wyrażania się, jeśli wcześniej uznamy, że istnieje coś, co zasługuje na specjalne nazewnictwo.

Wydaje mi się, że Kerry nie rozumie moich poglądów, ponieważ nieświadomie myli swój sposób użycia wyrazu „pojęcie” z moim. To zaś z łatwością prowadzi do sprzeczności i nie jest temu winny mój sposób użycia tego terminu.

[193] Kerry sprzeciwia się temu, co nazywa moją definicją „pojęcia”. Chciałbym na początku zaznaczyć, że moje wyjaśnienie nie było definicją we właściwym tego słowa znaczeniu. Tak jak nie można oczekiwać, że chemik rozłoży każdą substancję, tak nie można oczekiwać, że wszystko da się zdefiniować. Tego, co jest proste, nie można rozłożyć, a tego, co jest logicznie proste, nie można właściwie zdefiniować. Podobnie jak większość pierwiastków chemicznych również to, co logicznie proste, nie jest nam dane od początku. Można do tego dotrzeć tylko poprzez pracę naukową. Jeżeli odkryjemy coś, co jest proste, albo przynajmniej tymczasowo musi być uznane za proste, trzeba będzie ukuć nazwę dla tego odkrycia, ponieważ zastany język nie będzie zawierał dokładnie odpowiadającego mu wyrażenia. Przy wprowadzaniu nazwy dla czegoś logicznie prostego definicja nie jest możliwa. Możemy najwyżej za pomocą wskazówek naprowadzić czytelnika lub słuchacza na właściwe rozumienie tego słowa.

Kerry nie chce, żeby rozróżnienie między pojęciem i przedmiotem uchodziło za absolutne. Stwierdza: „sami wcześniej wyraziliśmy pogląd, że relacja między treścią pojęcia a przedmiotem pojęcia jest, pod pewnym względem, specyficzna i nieredukowalna. Pogląd ten nie jest bynajmniej związany z innym poglądem, że własności bycia pojęciem i bycia przedmiotem wzajemnie 
się wykluczają. Ten ostatni pogląd nie wynika z pierwszego, tak jak z tego, że relacja między ojcem i synem jest nieredukowalna, nie wynika to, że człowiek nie może być synem i ojcem jednocześnie (chociaż oczywiście nie chodzi tutaj o to, że np. ktoś jest synem i ojcem tej samej osoby jednocześnie)".

Przyjrzyjmy się temu porównaniu! Jeżeli istniałyby istoty, które wprawdzie są ojcami, ale nie mogą być synami, byłyby one oczywiście zupełnie innego rodzaju niż wszyscy ludzie, którzy są synami. Z czymś podobnym mamy do czynienia tutaj. Pojęcie, zgodnie z moim rozumieniem tego słowa, jest predykatywne ${ }^{3}$. Z drugiej strony nazwa przedmiotu - imię własne - w żadnym wypadku nie może być użyta jako orzeczenie gramatyczne. Oczywiście to wymaga wyjaśnienia, ponieważ może wydawać się fałszem. Czy nie można równie dobrze powiedzieć, że coś jest Aleksandrem Wielkim, liczbą cztery albo planetą Wenus, tak jak można powiedzieć, że jest zielone albo jest ssakiem? [194] Jeżeli ktoś tak uważa, to znaczy, że nie rozróżnia sposobów użycia słowa ,jest”. W ostatnich dwóch przykładach pełni ono rolę łącznika, zwykłego formalnego znaku orzekania (Formwort der Aussage). [W języku niemieckim] może być ono czasami zastąpione przez zwykłą końcówkę osobową. Na przykład „dieses Blatt ist grün (ten liść jest zielony)” i „dieses Blatt grünt (ten liść zieleni się)”. W takim przypadku mówimy, że coś podpada pod pojęcie, a orzeczenie gramatyczne oznacza to pojęcie. Natomiast w pierwszych trzech przykładach słowo „jest” zostało użyte tak, jak arytmetyczny znak równości, żeby wyrazić równanie ${ }^{4}$. W zdaniu „Wenus jest Gwiazdą Poranną" mamy dwa imiona własne dla tego samego przedmiotu: „Gwiazda Poranna” i „Wenus”. W zdaniu "Gwiazda Poranna jest planetą” mamy imię własne „Gwiazda Poranna” i oznaczający pojęcie predykat „planeta”. Pod względem językowym nie zaszło tutaj nic więcej niż to, że słowo „Wenus” zostało zastąpione przez słowo „planeta”. Mamy tutaj jednak do czynienia z zupełnie inną relacją. Równanie jest odwracalne (umkehrbar), a podpadanie

$3 \mathrm{~W}$ zasadzie jest to odniesienie do orzeczenia gramatycznego.

4 Używam słowa „równy” i symbolu „=” w sensie „taki sam jak”, „nic innego niż”, „identyczny z”. Por. Ernst Schröder, Vorlesungen über die Algebra der Logik, t. 1 (Leipzig: Teubner, 1890), \$1, przy czym należy skrytykować Schrödera za to, że nie rozróżnia dwóch zasadniczo różnych relacji: przedmiotu od pojęcia, pod które podpada, oraz podrzędności jednego pojęcia względem drugiego. Jego uwagi dotyczące pełnego pierwiastka kwadratowego (Vollwurzel) również budzą wątpliwości. Schrödera symbol „€” nie oznacza po prostu łącznika. 
przedmiotu pod pojęcie jest relacją nieodwracalną (nicht umkehrbare) ${ }^{5}$. "Jest” w zdaniu „Wenus jest Gwiazdą Poranną" nie stanowi oczywiście zwykłego łącznika, lecz jest istotną częścią orzeczenia, również pod względem treści, w taki sposób, że w słowie „Wenus” nie zawiera się całe orzeczenie ${ }^{6}$. Można byłoby też powiedzieć: „Gwiazda Poranna nie jest różna od Wenus”. W takiej sytuacji to, co było wcześniej wyrażone wprost w pojedynczym słowie „jest”, teraz rozkłada się na cztery słowa „nie jest różna od” i wyraz „jest” pełni rolę zwykłego łącznika. A zatem tym, o czym się tutaj mówi, nie jest [pojęcie] Wenus, lecz [pojęcie] nie jest różna od Wenus. Te słowa oznaczają pojęcie, pod które podpada tylko jeden jedyny przedmiot. Mimo to należy zawsze odróżniać pojęcie od przedmiotu. Mamy tutaj słowo „Wenus”, które nigdy nie będzie orzeczeniem, [195] chociaż może być jego częścią. Znaczenie $^{8}$ tego słowa nigdy nie może być pojęciem, lecz jedynie przedmiotem. Również Kerry nie zaprzeczyłby, że w pewnym sensie tak jest. Tym samym jednak musiałby się zgodzić na rozróżnienie, którego uznanie jest bardzo ważne, między tym, co może być przedmiotem, a wszystkim innym. I to rozróżnienie nie zniknęłoby nawet wtedy, gdyby prawdą był pogląd Kerry’ego, że pewne pojęcia mogą być również przedmiotami.

Istnieją oczywiście przypadki, które zdają się wspierać jego stanowisko. Sam wskazywałem (w Podstawach \$53, na końcu), że pewne pojęcie może podpadać pod pojęcie wyższego stopnia, przy czym nie należy tego mylić

5 [Jak się zdaje, przez „odwracalność” i „nieodwracalność” Frege rozumie tutaj symetryczność i niesymetryczność relacji. W przypadku relacji równości mamy do czynienia z relacją symetryczną, np. w zdaniu „Wenus jest Gwiazdą Poranną” zachodzi równoważność zdań „Wenus = Gwiazda Poranna” i „Gwiazda Poranna = Wenus”. W przypadku relacji podpadania przedmiotu pod pojęcie nie jest tak, że pojęcie może podpadać pod przedmiot, a zatem symetryczność tutaj nie zachodzi].

${ }^{6}$ Por. moje Podstawy $\$ 66$.

7 Por. moje Podstawy $\$ 51$.

8 Por. mój artykuł „Über Sinn und Bedeutung”, który wkrótce pojawi się w Zeitschrift für Philosophie und philosophische Kritik. [Zob. polskie przekłady: Gottlob Frege, „Sens i znaczenie", w: Gottlob Frege, Pisma semantyczne, przeł. Bogusław Wolniewicz (Warszawa: Wydawnictwo Naukowe PWN, 1977); Gottlob Frege, „Sens i nominat”, w: Logika i język: studia z semiotyki logicznej, przeł. i red. Jerzy Pelc (Warszawa: Wydawnictwo Naukowe PWN, 1967). W niniejszym tłumaczeniu przy przekładzie słów „Sinn” i „Bedeutung” korzystamy z przekładu Wolniewicza]. 
z podrzędnością jednego pojęcia względem drugiego9. Kerry nie odnosi się do powyższego poglądu, ale daje następujący przykład: „pojęcie (der Begriff) "koń" " jest pojęciem (ein Begriff) łatwym do uchwycenia" i uważa, że pojęcie „koń” jest przedmiotem, a w zasadzie jednym z przedmiotów podpadających pod pojęcie „pojęcia łatwego do uchwycenia”. Otóż to! Dwa słowa „pojęcie (der Begriff) »koń «” w rzeczy samej oznaczają przedmiot, ale właśnie z tego powodu nie oznaczają pojęcia zgodnie $\mathrm{z}$ moim sposobem użycia tego słowa. To się w pełni zgadza z podanym przeze mnie kryterium, że w odróżnieniu od rodzajnika nieokreślonego ${ }^{10}$, który poprzedza predykat, rodzajnik określony w liczbie pojedynczej zawsze wskazuje jeden przedmiot ${ }^{11}$.

Kerry uważa, że żadne reguły logiczne nie mogą opierać się na językowych rozróżnieniach. Mojego rozróżnienia nie może uniknąć nikt, kto ustanawia takie reguły. Jest tak dlatego, że nie możemy porozumiewać się bez języka i ostatecznie zawsze musimy zawierzyć, że inni ludzie zrozumieją słowa, fleksję i budowę zdań tak samo jak my. Jak już wcześniej mówiłem, nie próbowałem podać definicji [pojęcia], lecz jedynie wskazówki: do tego momentu zdawałem się na ogólne wyczucie języka niemieckiego. Sprzyja mi przy tym to, że rozróżnienie językowe zgadza się z obiektywnym rozróżnieniem. W przypadku rodzajnika nieokreślonego nie ma prawdopodobnie żadnych wyjątków dla naszej reguły, pomijając przestarzałe sformułowania, takie jak „Ein edler Rat”. Sprawa nie jest taka prosta w przypadku rodzajnika określonego, zwłaszcza w liczbie mnogiej, [196] ale moje kryterium nie dotyczy tego przypadku. W odniesieniu do liczby pojedynczej, jak sądzę, sprawa wydaje się wątpliwa tylko wtedy, gdy liczba pojedyncza zastępuje liczbę mnogą, tak jak w zdaniach „Turek (der Türke) oblegał Wiedeń” i „koń (das Pferd) to zwierzę czworonożne". Z łatwością zauważamy, że te przypadki są wyjątkowe, dlatego też nasza reguła nie traci na wartości z powodu ich występowania. Jasne jest,

9 [Omówienie tego rozróżnienia można znaleźć w artykule: Woosuk Park, „Frege’s Distinction Between Falling Under and Subordination", w: Woosuk Park, Philosophy's Loss of Logic to Mathematics (Springer, 2018), 9-30].

10 [Na przykład „ein Mensch” oznacza jakiegoś człowieka, a „der Mensch” określonego człowieka. W języku polskim nie używamy takich rodzajników do wskazywania określoności lub nieokreśloności. Wystarczy nam kontekst wypowiedzi. W tym artykule istotne będą jednak różne subtelne rozróżnienia dotyczące rodzajników, dlatego też tam, gdzie będzie to potrzebne, będziemy podawać niemieckie wersje z rodzajnikiem].

11 Podstawy $\$ 51, \$ 66, \$ 68,80$. 
że w pierwszym zdaniu „Turek” to nazwa własna ludu. Drugie zdanie najlepiej byłoby potraktować jako wyrażające sąd ogólny, ̇̇e „wszystkie konie są zwierzętami czworonożnymi” albo „wszystkie prawidłowo zbudowane konie są czworonożnymi zwierzętami", ale te przypadki omówimy później ${ }^{12}$. Jeżeli Kerry uznaje, że moje kryterium jest nieprawidłowe, i twierdzi, że w zdaniu: „pojęcie (der Begriff), o którym teraz właśnie mówię, jest pojęciem jednostkowym (ein Individualbegriff)", nazwa składająca się z pierwszych sześciu słów oznacza jedno pojęcie, to rozumie on słowo "pojęcie” inaczej niż ja i sprzeczność nie tkwi w moich ustaleniach. Ale nikt nie może ode mnie żądać, żeby mój sposób wyrażania się był zgodny ze sposobem Kerry’ego.

Musimy oczywiście mieć na uwadze, że w sposób nieuchronny mierzymy się z niedoskonałościami języka, gdy twierdzimy, że pojęcie koń nie jest żadnym pojęciem ${ }^{13}$, podczas gdy np. [197] miasto (die Stadt) Berlin jest miastem (eine Stadt), a wulkan (der Vulkan) Wezuwiusz jest wulkanem (ein Vulkan). Język stawia nas tutaj w sytuacji bez wyjścia, co jest uzasadnieniem odstępstwa od uzusu językowego. Na wyjątkowość tego przypadku wskazuje sam Kerry, ujmując słowo „koń” w cudzysłów - ja używam w tym celu kursywy. Nie mieliśmy powodu, aby wyróżniać wyrazy „Berlin” i „Wezuwiusz” w podobny sposób. W dyskusji logicznej często odczuwa się potrzebę powiedze-

12 Wydaje mi się, że współcześnie przejawiamy tendencję do przesadnego rozciągania zasięgu [stosowalności] twierdzenia, że wyrażenia językowe nigdy nie są całkowicie równoważne i że słowo nigdy nie może być całkowicie oddane w innym języku. Ktoś nawet może pójść krok dalej i powiedzieć, że to samo słowo nigdy nie jest używane w ten sam sposób przez ludzi, którzy posługują się tym samym językiem. Nie chcę przesądzać, na ile prawdziwe jest to twierdzenie, lecz tylko podkreślić, że nierzadko w różnych wyrażeniach występuje coś wspólnego, co nazywam sensem, a w zdaniach w szczególności nazywam myślą. Innymi słowy: nie wolno nam ignorować tego, że ten sam sens, ta sama myśl mogą być różnie wyrażone, przy czym ta różnica nie dotyczy sensu, lecz jedynie ujęcia, naświetlenia albo zabarwienia myśli i jest w logice nieistotna. Może być tak, że jedno zdanie nie przekazuje ani więcej, ani mniej informacji niż drugie, i pomimo całej różnorodności języków ludzkość ma wspólny zbiór myśli. Jeżeli ktoś chciałby zabronić jakichkolwiek przekształceń wyrażeń pod pretekstem, że wraz z nimi zmieniłaby się również treść wyrażeń, logika zostałaby sparaliżowana, ponieważ zadanie logiki nie może być wykonane bez próby rozpoznania myśli w jej różnorodnych przebraniach. Musielibyśmy również odrzucić wszystkie definicje jako błędne.

${ }^{13}$ Coś podobnego ma miejsce wówczas, gdy o zdaniu "ta róża jest czerwona” mówimy: orzeczenie gramatyczne „jest czerwona” odnosi się do podmiotu „ta róża”. Tutaj słowa „podmiot gramatyczny "jest czerwony " nie są orzeczeniem gramatycznym, lecz podmiotem. Właśnie dlatego, że wprost nazywamy te słowa orzeczeniem, pozbawiamy je tej własności. 
nia czegoś o pojęciu i wyrażenia tego za pomocą formy typowej dla takich wypowiedzi, tzn. ujęcia tego, co jest wypowiedziane, jako treści orzeczenia gramatycznego. Można by się zatem spodziewać, że znaczeniem podmiotu gramatycznego jest pojęcie, ale zważywszy na jego predykatywną funkcję, pojęcie jako takie nie może pełnić tej roli, lecz musi najpierw zostać przekształcone w jakiś przedmiot albo - mówiąc precyzyjniej - być reprezentowane przez jakiś przedmiot, który oznaczamy, umieszczając przed nim rodzajnik „der Begriff”.

\section{„Pojęcie człowiek (der Begriff Mensch) jest niepuste”.}

Pierwsze dwa słowa [pierwsze trzy słowa w języku niemieckim, tzn. „der Begriff Mensch"] w tym zdaniu należy uznać za imię własne ${ }^{14}$, którego nie można używać jako orzeczenia, tak samo jak w przypadku słów „Berlin” albo „Wezuwiusz”. Kiedy mówimy „Jezus podpada pod pojęcie człowiek”, to pomijając łącznik, orzeczeniem jest tutaj

„ktoś podpadający pod pojęcie człowiek (der Begriff Mensch)” i oznacza to samo, co:

„człowiek (ein Mensch)”

Ale połączenie słów

"pojęcie człowiek (der Begriff Mensch)"

jest tylko częścią tego orzeczenia.

Ktoś mógłby zaprzeczyć predykatywnej naturze ${ }^{15}$ pojęcia, wskazując, że mówimy przecież o pojęciu podmiotu. Ale nawet w takich przypadkach, jak na przykład w zdaniu

14 Imieniem własnym nazywam cokolwiek, co jest znakiem przedmiotu.

15 To, co nazywam tutaj predykatywną naturą pojęcia, jest po prostu szczególnym przypadkiem potrzeby uzupełnienia, [przypadkiem] „nienasycenia”, które w mojej pracy Funktion und Term uznałem za istotną własność funkcji. Uniknięcie wyrażenia „funkcja $F(x)$ ” nie było tam możliwe, chociaż też pojawił się taki problem, że odniesienie tego wyrażenia nie jest funkcją. [Frege uważa, że funkcje różnią się od liczb. Znak funkcji jest nienasycony w tym sensie, że wymaga dopełnienia znakiem liczby i ten znak nazywamy wtedy znakiem argumentu. 
„Wszystkie ssaki mają czerwoną krew”,

rozpoznajemy predykatywną naturę pojęcia, ponieważ moglibyśmy zamiast tego powiedzieć: [198]

„cokolwiek, co jest ssakiem, ma czerwoną krew”

albo:

„jeżeli coś jest ssakiem, to ma czerwoną krew”.

W moich Podstawach arytmetyki nie rozróżniałem jeszcze sensu i znaczenia ${ }^{16}$, dlatego też w wyrażeniu „treść możliwego sądu” zawarłem to, co oznaczam teraz oddzielnymi słowami „myśl” i „wartość logiczna”" Nie zgadzam się już z zamieszczonym tam wyjaśnieniem (tamże, s. 77), chociaż co do istoty mój pogląd się nie zmienił. Możemy w skrócie powiedzieć, przyjmując językowy sens słów „podmiot” i „orzeczenie”, że pojęcie jest znaczeniem orzeczenia, przedmiot zaś jest czymś, co nigdy nie może być całym znaczeniem orzeczenia, ale może być znaczeniem podmiotu. Musimy przy tym zaznaczyć, że zaimki „wszyscy”, „każdy”, „żaden”, „jakis'” poprzedzają predykat. W zdaniach ogólnych i szczegółowych, zarówno twierdzących, jak i przeczących, wyrażamy relacje między pojęciami. Zaimków zaś używamy, żeby wskazywać na relacje szczególnego rodzaju. Są one, logicznie rzecz ujmując, nie tyle ściśle związane z następującymi po nich słowami wyrażającymi pojęcia, ile z całym zdaniem. Łatwo to zobaczyć w przypadku negacji. Jeżeli w zdaniu

„Wszystkie ssaki są mieszkańcami lądu”

Własność niezupełności funkcji Frege przenosi teraz na pojęcie. Zob. np. Frege, Pisma semantyczne, 97].

16 Zob. mój esej „Über Sinn und Bedeutung” w Zeitschrift für Philosophie und philosophische Kritik.

17 [Frege wprowadza w tym eseju rozróżnienie na sens i znaczenie. Znaczeniem zdania w mowie niezależnej jest wartość logiczna, a jego sensem myśl, którą wyraża. Znaczeniem zdania w mowie zależnej (zdania pobocznego) jest sąd, a jego sensem - sens słów tworzących funktor (np. intensjonalny), który poprzedza to zdanie poboczne i który jest tylko częścią myśli odpowiadającej całemu zdaniu złożonemu]. 
zwrot „wszystkie ssaki” wyraża podmiot logiczny orzeczenia sq mieszkańcami ląu, to żeby zanegować całe zdanie, musielibyśmy zanegować orzeczenie: „nie są mieszkańcami lądu”. Zamiast tego musimy jednak umieścić „nie” przed „wszystkie”, z czego wynika, że „wszystkie” w sensie logicznym należy do orzeczenia. Z drugiej strony prawdą jest, że negujemy zdanie „pojęcie ssak jest podrzędne względem pojęcia mieszkaniec lądu” poprzez negację orzeczenia: „nie jest podrzędne względem pojęcia mieszkaniec lądu”.

Kiedy weźmiemy pod uwagę, że w mojej terminologii wyrażenia takie jak „pojęcie $F$ (der Begriff $F$ )” oznaczają nie pojęcia, lecz przedmioty, to zarzuty Kerry’ego są w największej mierze [199] nieważne. Jeżeli Kerry sądzi (por. s. 281), że utożsamiłem przedmiot i ekstensję pojęcia, to jest w błędzie. Wyraziłem jedynie opinię, że w zdaniu „liczba przysługująca pojęciu $F$ jest ekstensją pojęcia (der Umfang des Begriffes): pojęcie równoliczne z pojęciem F", słowa „ekstensja pojęcia (Umfang des Begriffes)” mogą być zastąpione przez wyraz „pojęcie (Begriff)”. Zauważmy, że słowo „pojęcie (Begriff)” jest połączone wtedy z rodzajnikiem określonym. Nawiasem mówiąc, była to tylko marginalna uwaga, na której niczego w moim wywodzie nie oparłem.

Chociaż Kerry'emu nie udaje się wypełnić luki między pojęciem i przedmiotem, ktoś mógłby spróbować, w takim sam sposób jak Kerry, zinterpretować moje wypowiedzi. Stwierdziłem, że podanie liczby jest sformułowaniem dotyczący pojęcia ${ }^{18}$; miałem na myśli własności, które są orzekane o pojęciu $\mathrm{i}$ to pojęcie podporządkowałem pojęciu wyższego stopnia ${ }^{19}$. Istnienie nazwałem własnością pojęcia. To, co chciałem tutaj wyrazić, najlepiej zilustrować przykładem. W zdaniu ,istnieje przynajmniej jeden pierwiastek kwadratowy z 4" nie mówię czegoś o określonej liczbie 2 ani o liczbie 2, lecz o pojęciu, pierwiastek kwadratowy z 4, że jest ono niepuste. Jeżeli jednak wyrażę tę samą myśl: „pojęcie pierwiastek kwadratowy $z 4$ jest zrealizowane”20, to te pierwsze pięć słów tworzy nazwę własną jakiegoś przedmiotu, a zatem to właśnie o tym przedmiocie coś stwierdzamy. Zauważmy jednak, że to zdanie nie jest tym samym, co zdanie o pojęciu. To może zaskoczyć tylko kogoś, kto nie dostrzega, że myśl można rozłożyć na wiele sposobów i że raz jedna rzecz, raz

\footnotetext{
18 Podstawy, $\$ 46$.

19 Podstawy, $\$ 53$.

20 [Jest zrealizowane (ist efrült) w sensie: posiada desygnaty, jest niepuste].
} 
inna występuje jako podmiot albo orzeczenie. Sama myśl nie przesądza jeszcze o tym, co jest podmiotem. Jeżeli powiemy: „podmiot tego sądu”, to wskazujemy na określone znaczenie tylko wówczas, gdy jednocześnie wskażemy określony rodzaj analizy. Przeważnie robimy to w odniesieniu do konkretnie dobranych słów. Nie wolno nam jednak nigdy zapominać, że różne zdania mogą wyrażać tę samą myśl. Na przykład myśl, którą tutaj rozważamy, może być również potraktowana jako twierdzenie o liczbie 4 :

„liczba 4 ma taką cechę pojęciową, że istnieje coś, czego ta liczba jest kwadratem".

Język ma środki, które pewnym częściom [200] myśli pozwalają występować $\mathrm{w}$ roli podmiotu. Jednym z najbardziej znanych środków językowych jest rozróżnienie na stronę czynną i bierną. Nie jest więc niemożliwe, żeby ta sama myśl występowała raz jako sąd jednostkowy (singulärer), inny razem jako sąd szczegółowy (partikulärer), a jeszcze innym razem jako sąd ogólny ${ }^{21}$. W związku z tym nikogo nie powinno dziwić, że to samo zdanie można rozumieć raz jako mówiące o pojęciu, innym razem o przedmiocie. Musimy mieć tylko na uwadze, że w każdym z tych przypadków orzekamy o czymś innym. W zdaniu „istnieje przynajmniej jeden pierwiastek kwadratowy z 4" nie da się zastąpić słów "pierwiastek kwadratowy z 4” "pojęciem pierwiastka kwadratowego $z$ ", tzn. wyrażenie, które pasuje do pojęcia, nie pasuje do przedmiotu. Mimo że nasze zdanie nie przedstawia pojęcia jako podmiotu, to jednak orzeka coś o nim. Można je rozumieć w ten sposób, że pewne pojęcie podpada pod pojęcie wyższego stopnia ${ }^{22}$. To jednak w ogóle nie zaciera różnicy między przedmiotem i pojęciem. Po pierwsze zauważmy, że w zdaniu „istnieje przynajmniej jeden pierwiastek kwadratowy z 4” pojęcie nie zaprzecza swojej predykatywnej naturze. Moglibyśmy powiedzieć: "istnieje coś, co pomnożone przez siebie równa się 4". Zatem to, co tutaj mówimy o pojęciu, nigdy nie może być powiedziane o przedmiocie, ponieważ

${ }^{21}$ [Frege wskazuje tu na trzy podstawowe formy sądów, które dotyczą ilości. A zatem chodzi o sądy jednostkowe, które mają formę „ten $F$ jest $G$ ”, sądy szczegółowe, które mają formę „jakieś $F$ są G” i sądy ogólne mające formę „wszystkie $F$ są G”].

${ }^{22} \mathrm{~W}$ moich podstawach nazwałem takie pojęcie pojęciem drugiego rzędu; w mojej pracy Funktion und Begriff nazwałem je pojęciem drugiego stopnia, tak jak to robię tutaj. 
imię własne nigdy nie może być wyrażeniem predykatywnym, chociaż może być jego częścią. Nie twierdzę, że mówienie tego samego o przedmiocie, co o pojęciu, jest fałszem, lecz że jest to niemożliwe i bezsensowne. Zdanie „istnieje Juliusz Cezar" nie jest ani prawdziwe, ani fałszywe, lecz jest pozbawione sensu, ale już zdanie „istnieje człowiek (einen Mann), którego imię to Juliusz Cezar" ma sens. Tyle że - zgodnie z tym, co sugeruje nam rodzajnik nieokreślony - znowu odnosimy się tutaj do pojęcia. To samo mamy w zdaniu „Wiedeń jest tylko jeden”. Nie dajmy się zwieść temu, że język niekiedy używa tego samego wyrazu raz jako imienia własnego, a innym razem jako predykatu. W naszym przykładzie cyfra wskazuje, że mamy do czynienia z drugim przypadkiem. „Wiedeń” jest tutaj predykatem, tak jak „metropolia”. Używając w tym sensie słowa „Wiedeń”, możemy powiedzieć: „Triest to nie jest Wiedeń”. Z drugiej strony, jeżeli w zdaniu „pojęcie pierwiastek z 4 [201] jest zrealizowane" zastąpimy imię własne, zbudowane z pierwszych czterech słów, wyrażeniem "Juliusz Cezar", to uzyskamy zdanie, które ma sens, lecz jest fałszywe. O tym, że coś jest zrealizowane (zgodnie z naszym użyciem tego słowa), można w istocie powiedzieć tylko wtedy, gdy mamy do czynienia ze specjalnym rodzajem przedmiotów, które są oznaczane przez imiona własne o postaci "pojęcie $F$ ". A zatem słowa "pojęcie pierwiastek kwadratowy z 4", ze względu na ich wymienialność, co do istoty zachowują się inaczej niż słowa "pierwiastek kwadratowy z 4" w naszym pierwotnym zdaniu, tzn. znaczenie tych dwóch połączeń słów jest zasadniczo różne ${ }^{23}$.

To, co pokazaliśmy tutaj na pojedynczym przykładzie, jest również ważne w ogólności: co do istoty pojęcie zachowuje się predykatywnie, nawet tam, gdzie się coś o nim twierdzi. W konsekwencji pojęcie może być wymienione tylko na inne pojęcie, nigdy zaś na przedmiot. A zatem to, co powiedzieliśmy o pojęciu, w ogóle nie dotyczy przedmiotu. Pojęcia drugiego stopnia, pod które podpadają pojęcia pierwszego stopnia, są co do istoty różne od pojęć pierwszego stopnia, pod które podpadają przedmioty. Relacja przedmiotu z pojęciem pierwszego stopnia, pod które podpada, różni się od - przyznaję, że podobnej - relacji pojęcia pierwszego stopnia z pojęciem drugiego stopnia. Być może, aby oddać sprawiedliwość zarówno temu rozróżnieniu, jak i podobieństwu, moglibyśmy powiedzieć, że przedmiot podpada pod (fallen

${ }^{23}$ Zob. mój esej Sens i znaczenie (cytowany wyżej). 
unter) pojęcie pierwszego stopnia, a pojęcie [pierwszego stopnia] pozostaje $w$ zasięgu (fallen in) pojęcia drugiego stopnia. A zatem rozróżnienie między pojęciem i przedmiotem wciąż pozostaje ostre.

Jest to związane z tym, co powiedziałem w $\$ 53$ Arytmetyki o moim sposobie używania wyrażeń „,echa pojęciowa ” $i$,cecha przedmiotowa”. $Z$ powodu uwag Kerry’ego raz jeszcze wracam do tych wątków. Słowa te służą do oznaczenia relacji w zdaniach typu „ $\Phi$ jest cechą pojęciową $\Gamma$ [gammy]” i „ $\Phi$ jest cechą przedmiotową w każdym miejscu $\Omega$ [omegi]". Zgodnie z moją terminologią coś może być zarazem cechą pojęciową i przedmiotową, ale nie może być cechą pojęciową i przedmiotową tej samej rzeczy. Pojęcia, pod które podpada jakiś przedmiot, nazywam jego cechami pojęciowymi, a zatem

$$
\text { „bycie } \Phi \text { jest cechą pojęciową } \Gamma \text { [gammy]” }
$$

to tylko inny sposób powiedzenia, że

$$
\text { „Г podpada pod pojęcie } \Phi ”
$$

Jeżeli przedmiot $\Gamma$ ma cechy pojęciowe $\Phi, X, \Psi$, to można je połączyć w $\Omega$ w taki sposób, że zdanie „Г ma cechę pojęciową $\Omega$ ” mówi to samo, co zdanie „Г ma cechę pojęciową $\Phi ”$ albo „Г [202] ma cechę pojęciową $\Phi, X, \Psi$. Nazywam wtedy $\Phi, X$ i $\Psi$ cechami przedmiotowymi pojęcia $\Omega$ i jednocześnie cechami pojęciowymi $\Gamma$ [gammy]. Rzeczą oczywistą jest, że relacje między $\Phi$ a $\Gamma$ i między $\Phi$ a $\Omega$ są od siebie zupełnie różne, a zatem konieczne są dla nich inne nazwy. $\Gamma$ podpada pod pojęcie $\Phi$, ale $\Omega$, która sama jest pojęciem, nie może podpadać pod pojęcie pierwszego stopnia, którym jest $\Phi$. W podobnej relacji może pozostawać tylko z pojęciem drugiego stopnia. $\Omega$, z drugiej strony, jest podrzędna względem pojęcia $\Phi$.

Spójrzmy na przykład! Zamiast mówić:

$$
\begin{gathered}
\text { „2 jest liczbą dodatnią" oraz } \\
\text { „2 jest liczbą całkowitą" oraz } \\
\text { „2 jest mniejsze od } 10 ”
\end{gathered}
$$


możemy również powiedzieć

„2 jest liczbą dodatnią całkowitą mniejszą od 10".

Tutaj wyrażenia

$$
\begin{aligned}
& \text { być liczba dodatnia } \\
& \text { być liczba całkowita } \\
& \text { być mniejsza od } 10
\end{aligned}
$$

występują jako cechy pojęciowe przedmiotu 2 , ale też jako cechy przedmiotowe pojęcia

\section{dodatnia liczba całkowita mniejsza od 10.}

To nie jest ani dodatnia liczba, ani całkowita, ani mniejsza od 10. To prawda, że jest podrzędna względem pojęcia liczby całkowitej, ale nie podpada pod nie.

Porównajmy to teraz z tym, co Kerry mówi w swoim drugim artykule (s. 424): „przez daną ${ }^{24}$ liczbę 4 (der Zahl 4) rozumiemy dany wynik (das Resultat) addytywnego połączenia 3 i 1 . Przedmiotem podanego tu pojęcia jest indywiduum liczbowe 4 - określona liczba w ciągu liczb naturalnych. Przedmiot ten oczywiście jest nośnikiem dokładnie tych samych cech, które są nazwane w jego pojęciu, i nie ma innych poza nimi, pod warunkiem że powstrzymamy się, co z pewnością powinniśmy zrobić, od uznania nieskończenie wielu relacji, w jakich pozostaje on ze wszystkimi innymi indywiduami liczbowymi, za jego propria: „dana” liczba 4 („die” 4) jest również danym wynikiem addytywnego (das Resultat) połączenia 3 i 1”.

Od razu widać, że moje rozróżnienie między cechą pojęciową a cechą przedmiotową jest tutaj całkowicie zatarte. Kerry odróżnia daną liczbę 4 (der Zahl 4) od „danej” liczby 4 („der” Zahl 4). Muszę przyznać, że nie rozumiem

${ }^{24}$ [W tym momencie istotne staje się rozróżnienie rodzajników ujętych w cudzysłów i nieujętych w cudzysłów. Wyjątkowo teraz zastąpimy te rodzajniki określone wyrażeniami „dany”, „dana”, „dane”]. 
tego rozróżnienia. Dana liczba 4 (die Zahl 4) powinna być pojęciem, a „dana” liczba 4 („die” Zahl 4) powinna być przedmiotem pojęcia i niczym innym, jak właśnie indywiduum liczbowym 4 . Nie trzeba [203] dowodu, żeby dostrzec, że takie odróżnienie przedmiotu od pojęcia nie jest moje. Można odnieść wrażenie, jak gdyby Kerry miał tutaj na myśli, aczkolwiek bardzo niejasno, wskazaną przeze mnie różnicę między sensem a znaczeniem słów „liczba 4 (die Zahl 4)"25. Ale jedynie o znaczeniu słów można powiedzieć, że są wynikiem addytywnego łączenia 3 i 1 .

Jak należy rozumieć słowo „jest” w zdaniach „dana liczba 4 (die Zahl 4) jest danym wynikiem (das Resultat) addytywnego łączenia 3 i 1" oraz „»dana« liczba 4 („die” Zahl 4) jest danym wynikiem (das Resultat) addytywnego łączenia 3 i 1"? Czy jest ono jedynie łącznikiem, czy też pomaga wyrazić równanie logiczne? W pierwszym przypadku z "dany wynik (das Resultat)” należałoby usunąć „dany (das)” sprzed słowa „wynik (Resultat)” i zdania wyglądałyby następująco:

$$
\begin{gathered}
\text { „Dana liczba } 4 \text { (die Zahl 4) jest wynikiem (Resultat) } \\
\text { addytywnego łączenia } 3 \text { i 1”; } \\
\text { „»Dana« liczba } 4 \text { („die” Zahl 4) jest wynikiem (Resultat) } \\
\text { addytywnego łączenia } 3 \text { i 1”. }
\end{gathered}
$$

W tym przypadku oba przedmioty, które oznacza Kerry nazwami

„dana liczba 4 (die Zahl 4)” i „»dana« liczba 4 (»die« Zahl 4)”

podpadałyby pod pojęcie

$$
\text { wynik addytywnego łaczenia } 3 \text { i } 1 \text {. }
$$

Pozostaje zatem tylko pytanie, czym różnią się te przedmioty. Używam tutaj słów „przedmiot” i „pojęcie” w przyjęty przeze mnie sposób. To, co próbuje powiedzieć Kerry, ująłbym następująco:

\footnotetext{
25 Por. mój wyżej wspomniany esej o sensie i znaczeniu.
} 
„Liczba 4 ma takie cechy pojęciowe, i tylko takie, które są cechami przedmiotowymi pojęcia wynik addytywnego łączenia 3 i 1".

Wtedy powinienem wyrazić sens pierwszych dwóch zdań następująco:

$$
\begin{gathered}
\text { „Bycie liczbą } 4 \text { jest tym samym, co bycie wynikiem } \\
\text { addytywnego łączenia } 3 \text { i 1", }
\end{gathered}
$$

a wtedy to, co uznałem za pogląd Kerry’ego, można by również sformułować w taki sposób:

„Liczba ma takie cechy pojęciowe, i tylko takie, które są cechami przedmiotowymi pojęcia liczba 4".

Nie musimy jeszcze tutaj decydować, czy to prawda. W słowach „»dana« liczba 4" (»die "Zahl 4) moglibyśmy pominąć cudzysłów ostrokątny.

Ale w naszych próbach interpretacyjnych założyliśmy, że przynajmniej $\mathrm{w}$ jednym $\mathrm{z}$ tych dwóch zdań rodzajniki określone przed słowami „wynik” (Resultat) i „liczba 4” (Zahl 4) zostały umieszczone przypadkowo. Jeżeli weźmiemy słowa takimi, jakimi są, ich sensem będzie równanie logiczne.

„Liczba 4 nie jest niczym innym, jak wynikiem addytywnego łączenia 3 i 1 ".

Rodzajnik określony przed słowem „wynik” (Resultat) jest tutaj uzasadniony logicznie tylko wtedy, gdy uznano, (1) że jest taki wynik i (2) że jest tylko jeden taki wynik. Takie połączenie słów oznacza wtedy przedmiot i należy je rozumieć jako imię własne. Jeżeli oba nasze zdania miałyby być rozumiane jako równania logiczne, to wtedy, zważywszy na to, że ich prawe strony są identyczne, wynikałoby z nich, że dana liczba 4 (die Zahl 4) jest „daną” liczbą 4 („die” Zahl 4) albo, jeśli ktoś woli, że dana liczba 4 (die Zahl 4) nie jest niczym innym, jak „daną” liczbą 4 („die” Zahl 4). W ten sposób udowodnilibyśmy nieważność rozróżnienia Kerry’ego. Jednakże nie jest tutaj moim zadaniem wykazywać sprzeczności w jego prezentacji [moich poglądów]. To, co rozumie przez słowa „przedmiot” i „pojęcie”, właściwie nie jest tutaj moją sprawą. Chcę tylko przedstawić mój własny sposób używania tych słów w jaśniejszym świetle i przy okazji pokazać, że bądź co bądź różni się on 
od jego sposobu użycia, niezależnie od tego, czy zachodzą między nimi jakieś zgodności, czy też nie.

[204] Nie odmawiam Kerry’emu prawa do używania słów „przedmiot” i „pojęcie” wedle jego uznania, ale chciałbym skorzystać z tego samego prawa, aby stwierdzić, że za pomocą moich oznaczeń uchwyciłem rozróżnienie o najwyższej wadze. Pewną przeszkodą dla Czytelnika może być to, że niekiedy ze względu na pewien rodzaj konieczności językowej moje wyrażenie, wzięte literalnie, nie oddaje mojej myśli, nazywając przedmiot tam, gdzie mowa jest o pojęciu. Jestem w pełni świadomy tego, że w takich przypadkach muszę polegać na życzliwości Czytelnika, że zrobi to cum grano salis.

Ktoś mógłby pomyśleć, że mamy tutaj do czynienia ze sztucznie stworzoną trudnością, że nie ma potrzeby brania pod uwagę czegoś tak nieporęcznego jak to, co nazwałem pojęciem, i że można by było, podążając za Kerrym, uznać podpadanie przedmiotu pod pojęcie za relację, w której to samo raz może wystąpić jako przedmiot [205], a innym razem jako pojęcie. Słowa „przedmiot” i „pojęcie” służyłyby wtedy tylko do tego, żeby wskazywać inną pozycję w relacji. Można tak zrobić, ale ten, kto uwierzy, że w ten sposób uniknie trudności, jest w dużym błędzie. Trudność ulega jedynie przesunięciu, ponieważ nie wszystkie części myśli mogą być dokończone, to znaczy przynajmniej jedna z nich musi być w jakiś sposób „nienasycona”, czy też predykatywna, inaczej nie wiązałyby się ze sobą. Na przykład sens wyrażenia „liczba 2” nie wiąże się z sensem wyrażenia "pojęcie liczba pierwsza” bez łącznika. Takiego łącznika używamy w zdaniu „liczba 2 podpada pod pojęcie liczba pierwsza”. Łącznikiem są tutaj słowa „podpada pod”, które muszą być uzupełnione za pomocą podmiotu i biernika; i tylko z powodu „nienasycenia” ich sensu mogą pełnić rolę łącznika. Dopiero wtedy, gdy zostaną uzupełnione na te dwa sposoby, uzyskamy dokończony sens, mamy jakąś myśl. Chodzi mi tutaj o to, że takie słowa czy wyrażenia oznaczają relację. W przypadku relacji napotykamy tę samą trudność, której próbowaliśmy uniknąć w przypadku pojęcia. Słowa „relacja przedmiotu z pojęciem, pod które podpada” oznaczają nie relację, ale przedmiot, a trzy imiona własne „liczba 2", „pojęcie liczba pierwsza” i „relacja przedmiotu z pojęciem, pod które podpada" są od siebie tak samo odległe, jak te pierwsze dwa. Niezależnie od tego, jak je ze sobą zestawimy, [bez łącznika] nie otrzymamy zdania. Widać więc, że trudność, która powstaje $\mathrm{z}$ „nienasycenia" jakiejś części myśli, może być przesunięta, ale nie daje się jej uniknąć. 
Określenia „dokończona” i „nienasycona” są oczywiście tylko metaforami, ale w tym miejscu chciałbym i mogę podać jedynie wskazówki.

Zrozumienie [tego] może być łatwiejsze, jeśli Czytelnik porówna moją pracę Funktion und Begriff. Zastanawiając się nad pytaniem, czym jest to, co nazywamy funkcją w analizie, natrafiamy na tę samą przeszkodę. Po bliższym zbadaniu okazuje się, że ta przeszkoda jest istotna i zakorzeniona w samych rzeczach i naturze naszego języka; że nie można uniknąć pewnej nieadekwatności wyrażeń językowych i że nie można zrobić nic innego, niż zdać sobie $\mathrm{z}$ tego sprawę i zawsze brać to pod uwagę.

Przekład i opracowanie:

Rafał Michalski Uniwersytet Mikołaja Kopernika w Toruniu e-mail: metasis@umk.pl ORCID: 0000-0002-9587-5074

Patryk Popławski Uniwersytet Mikołaja Kopernika w Toruniu e-mail: patrycjusz220@gmail.com ORCID: 0000-0002-2212-3381 